\title{
Gamellia sinensis O.Ktze extract shows anti-colorectal cancer activity via MAPK/ERK signaling pathway
}

\author{
Min Lv' ${ }^{1}$, Bo Li ${ }^{2}$, Zhi-xuan Fü ${ }^{2}$, Yu-ping Zhu ${ }^{2 \star}$ \\ ${ }^{1}$ Department of Ultrasound, ${ }^{2}$ Department of Colorectal Cancer Surgery, Zhejiang Cancer Hospital, Hangzhou 310022, Zhejiang \\ Province, PR China
}

*For correspondence: Email: zhuyuping494@126.com; Tel: +86 0571-88128011

\begin{abstract}
Purpose: To investigate the therapeutic effects of Gamellia sinensis O.Ktze extract (GSOE) on colorectal cancers, as well as the underlying mechanisms.

Methods: The effect of GSOE on colorectal cancer cells HCT-116 or Caco-2 growth was tested, and then the apoptosis and invasion was analyzed by MTT, flow cytometry and Transwell assay in vitro. Next, the mice received three doses (200, 400 or $800 \mathrm{mg} / \mathrm{kg} /$ day, gastric perfusion) of GSOE to evaluate its effects on tumor growth. Lung metastasis in mouse xenograft models which were inoculated with HCT-116 or Caco-2 cells were also investigated. The expression of p-ERK and p-MEK were evaluated by western blot analysis in HCT-116 and Caco-2 cells with or without GSOE treatment in vitro.

Result: GSOE significantly inhibited colorectal cancer cell growth and induced apoptosis or cell cycle arrest at G1- and S-phases in HCT-116 cells and Caco-2 cells in a dose-dependent manner. Moreover, GSOE effectively retarded tumor cell migration and invasion through ERK/MAPK signaling pathway suppression.

Conclusion: These findings demonstrate that GSOE has an anti-tumor effect in colorectal cancer by inactivating ERK/MAPK signaling pathway.
\end{abstract}

Keywords: Gamellia sinensis O.Ktze, Colorectal cancer, Invasion, Apoptosis, Cell cycle arrest ERK, MAPK

\begin{abstract}
This is an Open Access article that uses a funding model which does not charge readers or their institutions for access and distributed under the terms of the Creative Commons Attribution License (http://creativecommons.org/licenses/by/4.0) and the Budapest Open Access Initiative (http://www.budapestopenaccessinitiative.org/read), which permit unrestricted use, distribution, and reproduction in any medium, provided the original work is properly credited.

Tropical Journal of Pharmaceutical Research is indexed by Science Citation Index (SciSearch), Scopus, International Pharmaceutical Abstract, Chemical Abstracts, Embase, Index Copernicus, EBSCO, African Index Medicus, JournalSeek, Journal Citation Reports/Science Edition, Directory of Open Access Journals (DOAJ), African Journal Online, Bioline International, Open-J-Gate and Pharmacy Abstracts
\end{abstract}

\section{INTRODUCTION}

Colorectal cancer has an incidence of approximately 150,000 per year in the United States and is the third leading cause of cancerrelated deaths in both men and women [1]. Although surgery, chemotherapy and radiotherapy [2-4] have been the mainstay of colorectal cancer treatment, traditional Chinese medicine (TCM) has the advantage of reducing cancer therapy-induced toxicity and is a popular form of complementary and alternative medicine (CAM) in China [5]. In recent years, with increased popularity with patients in China, the traditional Chinese medicine has been shown to further minimize the side effects of surgery, radiation and chemotherapy [6], increase immune function [7] and improve survival [8]. 
Gamellia sinensis O.Ktze has been a widely used and well-documented medicinal plant for centuries $[9,10]$. However, the anticancer properties of Gamellia sinensis O.Ktze have not been fully investigated and proven. In this study, we aim to explore the mechanism of GSOE in colorectal cancer suppression.

\section{EXPERIMENTAL}

\section{Material}

Gamellia sinensis O.Ktze was collected from Zhangjiajie City, Hunan Province in China in May 2016. Taxonomic identification of the plant was performed by Professor Dan Wang of Zhejiang University of traditional Chinese medicine in China. A voucher specimen of herbarium (No. GSOE 20160508) was deposited in the College of Pharmacy, Zhejiang University of traditional Chinese medicine, China for future reference. GSOE was obtained by steeping the dried leaves of Gamellia sinensis O.Ktze in water at $60{ }^{\circ} \mathrm{C}$ three times, each for one hour before first drying in a oven and then freeze-drying the last extract thus obtained. One gram powder was equivalent to about $1.4 \mathrm{~g}$ crude samples. The yield was $71.43 \%$.

\section{Cell lines}

Human colorectal cancer HCT-116 cells and Caco-2 cells were obtained from the cell bank of the Chinese Academy of Sciences (CAS) and maintained in RPMI 1640 medium supplemented with $10 \%(\mathrm{v} / \mathrm{v})$ heat-inactivated fetal calf serum, $2 \mathrm{mM}$ glutamine, 100 units/ml penicillin, and 100 $\mu \mathrm{g} / \mathrm{ml}$ streptomycin (Invitrogen, Carlsbad, CA) at $37{ }^{\circ} \mathrm{C}$ in a $5 \% \mathrm{CO}_{2}$ humidified atmosphere. These two cell lines were used for testing the effects of GSOE on colorectal cancer.

\section{MTT assays}

To determine whether GSOE could suppress the growth of colorectal cancer cells, GSOE drug sensitivity in colorectal cancer cells was determined using the MTT assay. Briefly, cells were trypsinized and plated out into 96 well plates at a density of $3 \times 10^{3}$ cells per well. Cells were cultured overnight and re-fed with fresh medium containing various concentrations of GSOE (10, 50 or $100 \mathrm{mg} / \mathrm{mL})$. The cell viability was examined at $0,12,24,36$ and $48 \mathrm{~h}$ after GSOE was added. Thereafter, $50 \mu \mathrm{L}$ 3-(4, 4dimethylthiazol-2-yl)-2, 5-dipheny-Itetrazolium bromide (MTT) (Sigma-Aldrich, St. Louis, MO) in PBS was added to each well, incubated for $4 \mathrm{~h}$ at $37{ }^{\circ} \mathrm{C}$ and the formazan crystals that formed were dissolved in $150 \mu \mathrm{L}$ dimethyl sulfoxide. The optical density was recorded at $490 \mathrm{~nm}$ on a micro-plate reader (Bio-Rad, Hercules, CA).

\section{Flow cytometry analysis}

To determine apoptosis of colorectal cancer cells, HCT-116 and Caco-2 cells were seeded in 6 -well plates $\left(4 \times 10^{5} /\right.$ well $)$ and treated with 100 $\mathrm{mg} / \mathrm{ml}$ GSOE for $24 \mathrm{~h}$, every group had 3 replicates. The cells were subjected to flow cytometry analysis using annexin $\mathrm{V}$ apoptosis detection kit (Becton Dickinson, NJ, USA). The cells were stained with annexin V-fluorescein isothiocyanate (FITC), propidium iodide (PI) for $25 \mathrm{~min}$, and then analyzed by flow cytometry (Thermo Fisher, USA). FACS data were analyzed using FlowJo software (Tree Star, Inc.). For cell cycle analysis, cells were fixed with 500 $\mu \mathrm{L}$ of pre-cooling $70 \%$ ethanol at $4{ }^{\circ} \mathrm{C}$ overnight. Then, $300 \mu \mathrm{L}$ of RnaseA-containing PI staining solution was added to incubate at room temperature for $30 \mathrm{~min}$. After washing with PBS, the absorbance was measured with flow cytometry and the results were analyzed using ModiFit.

\section{Tumor animal model}

Six to eight-weeks-old BALB/c (nu/nu) mice were purchased from Shanghai SLAC Laboratory Animal Co. All mice were maintained in a barrier facility at the Animal Center of Zhejiang University. The animals had free access to food and water, and were allowed to acclimatize for at least one week before use. The rat experiment was approved by the Animal Care and Use Committee of Zhejiang University (approval ref no. 201250306) and was carried out in compliance with Directive 2010/63/EU on the handling of animals used for scientific purposes [11].

HCT-116 or Caco-2 cells with the concentration of $1.0 \times 10^{6}$ were implanted subcutaneously (s.c.) into the right flank of the mice. All tumor-bearing mice were randomly divided into four groups with 5 mice per group. The mice received 200, 400 or $800 \mathrm{mg} / \mathrm{mL}$ of GSOE by gastric perfusion everyday post tumor cell inoculation. Untreated mice were considered as the control. Tumor volume was measured every two days. After the mice were sacrificed, the lungs were removed and immersed in cold PBS for $2-3 \mathrm{~h}$, the gray nodules on the surface of the lungs were counted.

\section{Western blot analysis}

HCT-116 and Caco-2 cells were treated with 10, 50 or $100 \mathrm{mg} / \mathrm{mL}$ GSOE for $24 \mathrm{~h}$, untreated cells 
were considered as the group control. All cells were treated with RIPA lysis buffer (Beyotime, China) containing protease inhibitor cocktail (Roche, Mannheim, Germany). Protein were separated by sodium dodecyl sulfatepolyacrylamide gel electrophoresis (SDS-PAGE) and transferred to a nitrocellulose membrane. After blocking with $5 \%$ fat-free milk, the membrane was probed with primary anti-p-ERK (dilution 1 : 1000; Cell Signal Technology), anti-p-MEK (dilution 1 : 1000, Santa Cruz) and anti-Actin (dilution 1 : 2000; Santa Cruz) antibody. After washing, the membrane was incubated with horseradish peroxidase-conjugated (HRP) secondary antibody for $1 \mathrm{~h}$. The signal was visualized using the ECL detection system (Thermo Fisher, USA) and quantified by densitometry using Quantity One software (BioRad, Hercules, CA, USA).

\section{Invasive assay}

Transwell chambers with Matrigel (BD Bioscience, USA) were used to evaluate the cell invasion. HCT116 or Caco-2 cells were incubated with or without $100 \mathrm{mg} / \mathrm{ml}$ GSOE in the upper chambers of a Transwell plate (Corning, USA) with serum-free medium. Lower chambers with polycarbonate membranes, received $10 \%$ FBS-containing medium, served as the attractant. After $24 \mathrm{~h}$, the cells in the upper chambers were removed; migrated cells on the lower side were observed after they were fixed with $4 \%$ paraformaldehyde and stained with crystal violet under a microscope. Migrating cells in five fields on each chamber were counted to calculate the invasion of colorectal cancer cells.

\section{Statistical analysis}

Statistical analysis was performed for all the data using Student's $t$-test. All the results are presented as mean \pm standard error of mean (SEM). $P<0.05$ was considered as statistically significant. All the tests were carried out using Prism 6 software (Graphpad Prism 6).

\section{RESULTS}

\section{GSOE suppresses the growth of colorectal cancer cells in vitro}

We tested the effects of GSOE on the growth of HCT-116 human colorectal cancer cells in vitro. GSOE induced a concentration-dependent decrease in cell growth and cell viability in HCT116 (Figures $1 \mathrm{~A}$ and $1 \mathrm{~B}$ ) and Caco-2 cells (Figures 1C and 1D), as analyzed by MTT assay. These data indicated that GSOE suppresses the growth of colon cancer cells.
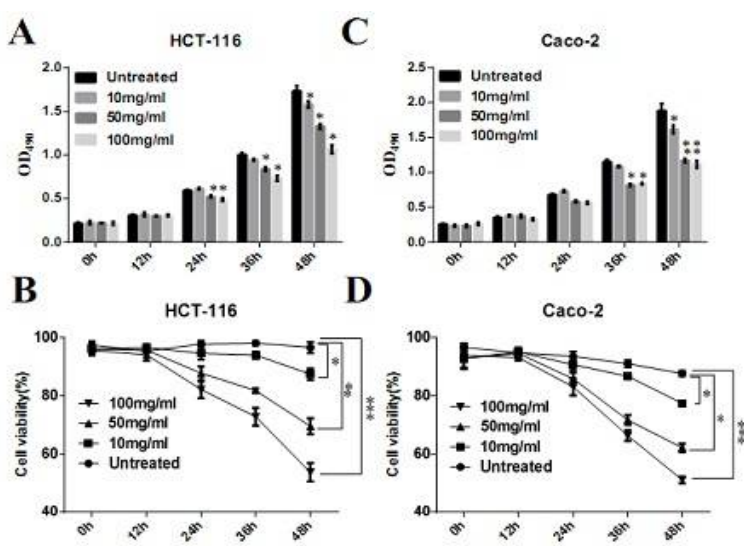

Figure 1: GSOE suppressed the growth of colorectal cancer cells in vitro. A and B: The growth curve and the inhibition rate of HCT-116 cells with GSOE treatment; $C$ and $D$ : The growth curve and the inhibition rate of Caco-2 cells with GSOE treatment. Data are shown as mean \pm SEM; * denotes $p<0.05$, denotes $p<0.01$, denotes $p<0.001$. The data represent 3 replicates

GSOE induces apoptosis and cell cycle arrest at G1 to $S$ phase in colorectal cancer cells

Flow cytometry analysis showed a significant increase in the number of cells in the proliferative G1- phase and a significant decrease in the number of cells in the G2-phase after $48 \mathrm{~h}$ of treatment with GSOE (Figure 2A). These results indicate cell cycle arrest at the S-phase after treatment of HCT-116 cells with GSOE. We evaluated the effects of GSOE on apoptosis in colorectal cancer cells by using Annexin V-FITC and $\mathrm{PI}$ staining. We observed a remarked increase in late apoptotic rate in both HCT-116 and Caco-2 cells, as assessed by flow cytometry, after GSOE treatment compared with untreated cells (Figure 2B). These data indicated that GSOE induced colorectal cancer cell death by promoting apoptosis promotion and cell cycle arrest.

The invasion of colorectal cancer cell is reduced by GSOE treatment

We examined whether GSOE attenuated the motility of colorectal cancer cells using transwell assay. Cell invasion increased after $24 \mathrm{~h}$ for the untreated group, but was substantially reduced when GSOE was present (Figure 3). These results suggest that GSOE inhibited invasion of colorectal cancer cells.

\section{GSOE suppresses growth and lung metastasis of colorectal cancer in vivo}

To extensively confirm our findings in vivo, we generated a xenograft mouse model inoculated 
with HCT-116 or Caco-2 cells. The growth of these two tumors was suppressed by GSOE (gastric perfusion) in a concentration-dependent manner (Figure 4A and 4B). Moreover, the metastasis in the lung was also remarkably reduced with GSOE treatment (Figure $4 \mathrm{C}$ and D). Taken together, we conclude that GSOE suppresses growth and lung metastasis of colorectal cancer.
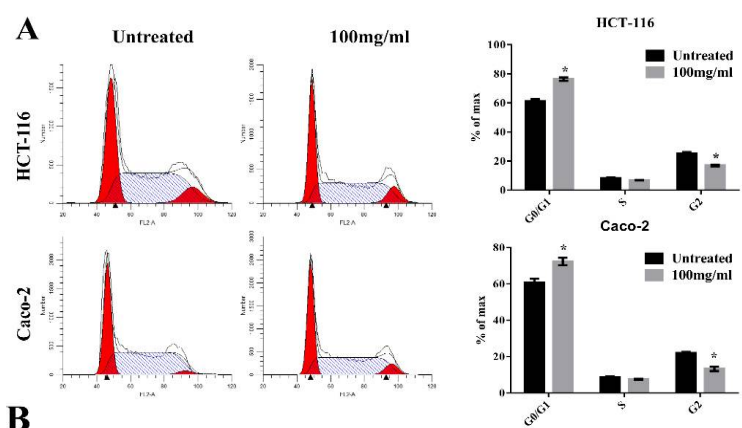

B

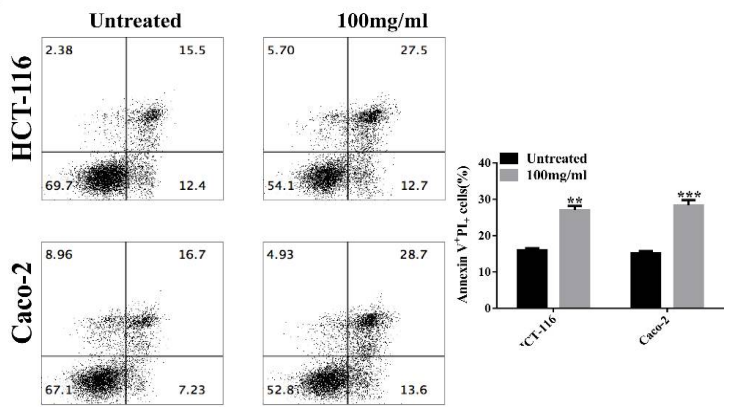

Figure 2: GSOE induced colorectal cancer cell apoptosis and cell cycle arrest in vitro. A. Flow cytometry analysis of HCT-116 (upper) and Caco-2 (lower) cell cycle with $100 \mathrm{mg} / \mathrm{ml}$ GSOE treatment. B. Flow cytometry analysis of HCT-116 (upper) and Caco-2 (lower) cell apoptosis with $100 \mathrm{mg} / \mathrm{ml}$ GSOE treatment. Data are shown as mean $\pm \mathrm{SEM}$; ${ }^{\text {* }}$ denotes $p<0.05$, denotes $p<0.01,{ }^{* * *}$ denotes $p<0.001$. The data represents 3 replicates

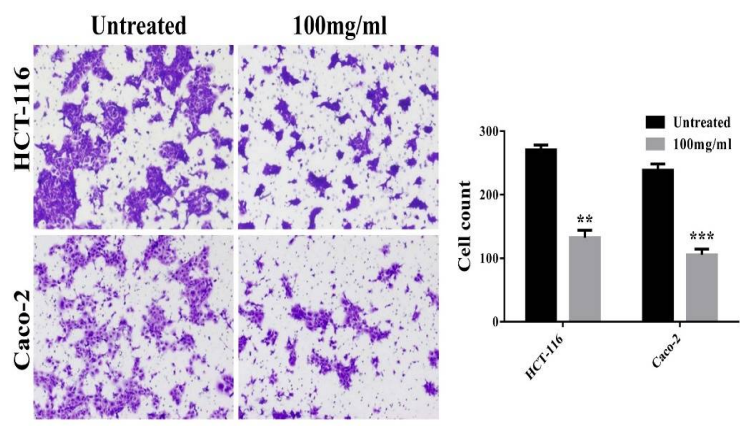

Figure 3: GSOE reduced colorectal cancer cell invasion in vitro. The invasion of HCT-116 and Caco-2 cells was determined by Transwell assays with 100 $\mathrm{mg} / \mathrm{mL}$ GSOE treatment. Data are shown as mean \pm SEM $(\mathrm{n}=3) ;{ }^{* *}$ denotes $p<0.01,{ }^{* * *}$ denotes $p<0.001$
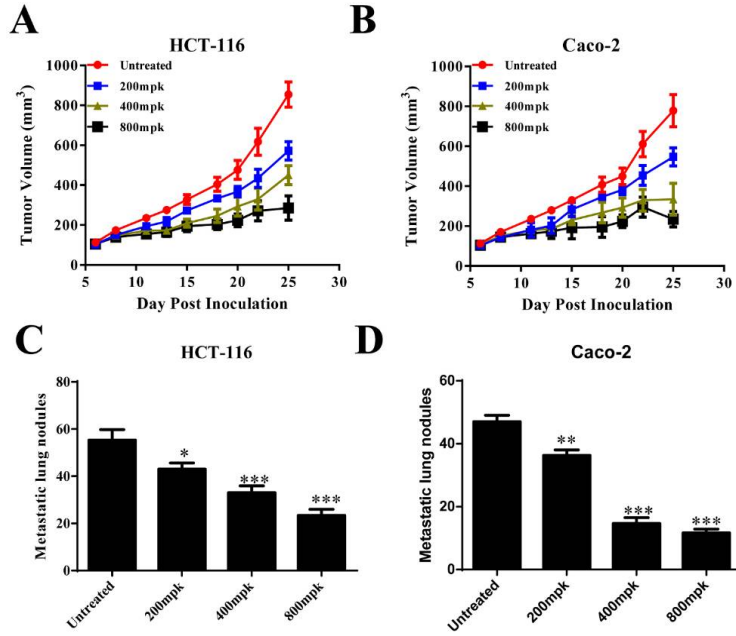

Figure 4: GSOE suppressed the growth and metastasis of colorectal cancer in a xenograft mouse model. A. The growth curve of tumors inoculated with HCT-116 cells which were treated with three concentrations $(200,400$ or $800 \mathrm{mg} / \mathrm{mL}$ per day) of GSOE by gastric perfusion. B. The growth curve of tumors inoculated with Caco-2 cells which were treated with three concentration $(200,400$ or 800 $\mathrm{mg} / \mathrm{mL}$ per day) of GSOE by gastric perfusion. C. The lung metastasis nodules of HCT-116 tumors were counted. D. The lung metastasis nodules of Caco-2 tumors were counted. Data are shown as mean \pm SEM $(\mathrm{n}=3)$; ${ }^{*}$ denotes $p<0.05,{ }^{\star *}$ denotes $p<0.01$, denotes $p<0.001$

\section{Effect of GSOE on ERK/MAPK signaling pathway in colorectal cancer cells}

In order to investigate the mechanism of inhibition of GSOE on colorectal cancer cells, we evaluated the effects of GSOE on ERK/MAPK signaling pathway in HCT-116 cells and Caco-2 cells. We determined the level of phosphorylation of ERK and MAPK which were treated with different concentration of GSOE for $24 \mathrm{~h}$. Western blot indicated that GSOE suppressed the phosphorylation of both ERK and MEK in HCT-116 cells or Caco-2 cells (Figure 5). All in all, we conclude that GSOE impairs ERK/MAPK signaling pathway to suppress the growth and invasion of colorectal cancer.

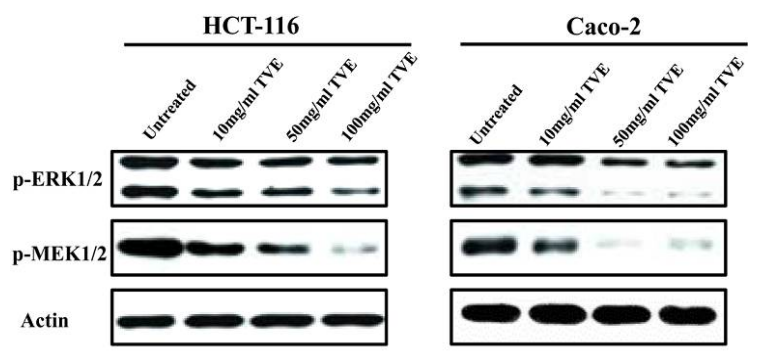

Figure 5: GSOE suppressed the phosphorylation of ERK1/2 and MEK1/2 in colorectal cancer cells in a concentration dependent manner. The phosphorylation of ERK and MEK were evaluated by 
western blot in HCT-116 (left) cells and Caco-2 (right) cells with 10,50 or $100 \mathrm{mg} / \mathrm{mL}$ GSOE treatment

\section{DISCUSSION}

Thea viridis (Camellia sinensis) is a species of plant whose leaves are used to produce Chinese and Indian teas. The leaves have been used in traditional Chinese medicine and other medical systems to treat asthma [12], peripheral vascular disease [13] and coronary artery disease [14,15]. The results of the present study show that GSOE acts as a tumor suppressor in colorectal cancers via apoptosis by ERK/MAPK signaling pathway inhibition.

Firstly, we used three concentration of GSOE to treated HCT-116 and Caco-2 cells which were both colorectal cancer cells. Using MTT assay, we confirmed that GSOE inhibited the growth of these two cells at different concentration of GSOE. In order to test how GSOE suppressed the growth of colorectal cancer cells, we explored the apoptotic rate of HCT-116 and Caco- 2 cells with GSOE treatment for about $24 \mathrm{~h}$. Flow cytometry analysis suggested that GSOE increased the apoptotic rate of the colorectal cancer cells. Moreover, we also showed that GSOE induced cell cycle arrest at G1 to S phase in colorectal cancer cells. These results indicated that the inhibitory role of GSOE in colorectal cancer cells was attributable to cell cycle arrest and induction of apoptosis.

Notably, approximately half of colorectal cancer patients develop distant metastases, especially lung metastases, which are the main cause of death in patients $[16,17]$. Tumor metastasis is a complex process that consists of multiple sequential steps, including the invasion of cancer cells into surrounding tissues, intravasation, extravasation, and growth in distant organs [18]. However, whether GSOE affected the metastasis of colorectal cancer was not clear. To address this question, we determined the invasion of HCT-116 and Caco-2 cells. To count the cells in lower chambers, we demonstrated that GSOE significantly inhibited the invasion of colorectal cancer cells in vitro. Furthermore, we also used xenograft tumor model to confirm the above results. As we expected, the HCT-116 and Caco2 tumor growth were suppressed with three different concentration of GSOE treatment and the lung metastase were decreased.

Mitogen-activated protein kinase (MAPK) pathways link extracellular signals to their intracellular targets and control fundamental cellular processes such as cell proliferation, cell growth, cell migration, cell differentiation and cell death [19]. GSOE treatment increases ROS generation through the action on calmodulindependent protein kinase kinase [20]. However, ROS can activate 5'-AMP-activated protein kinase (AMPK). Hwang et al. demonstrated that GSOE treatment of colon cancer cells resulted in a strong activation of AMPK in association with an inhibition of COX-2 expression [21]. The decreased COX-2 expression as well as prostaglandin E2 secretion was abolished by an AMPK inhibitor, Compound $\mathrm{C}$, suggesting that AMPK can be a target for an anti-cancer strategy. There are many molecules in MAPK signaling pathways such as ERK1/2, p38, MEK and JNK [22]. GSOE-derived-epigallocatechin gallate inhibits the growth of human villous trophoblasts via the ERK, p38, AMP-activated protein kinase, and AKT pathways. GSOE derived apigenin is also an invaluable chemopreventive agent that inhibits progression and metastasis of choriocarcinoma cells through regulation of PI3K/AKT and ERK1/2 MAPK signal transduction mechanism [23]. To investigate the mechanism of GSOE inhibition of colorectal cancer, we determined level of ERK signaling pathways including ERK1/2 and MEK. The result from western blot analysis indicated that the phosphorylation of ERK1/2 and MEK2 were remarkably decreased with PVE treatment of HCT-116 and Caco-2 cells.

\section{CONCLUSION}

The findings of this study show that GSOE suppresses colorectal cancer cell growth and metastasis which is attributable to the increased apoptotic rate and cell cycle arrest by ERK/MAPK signaling pathway inhibition. Thus, this agent has potentials to be developed for the management of colorectal cancer.

\section{DECLARATIONS}

\section{Acknowledgement}

This study was supported by Medical and Health Science and Technology Project of Zhejiang Province (no. 2013KYB046) and National Natural Science Fund (no. 81372210).

\section{Conflict of interest}

The authors declare that there is no conflict of interest with regard to this work.

\section{Contribution of authors}

We declare that this work was done by the authors named in this article and all liabilities 
pertaining to claims relating to the content of this article will be borne by the authors. Yu-ping Zhu designed and revised the manuscript, and Min $\mathrm{Lv}$, Bo $\mathrm{Li}$ and Zhi-xuan $\mathrm{Fu}$ finished the experiment.

\section{REFERENCES}

1. El-Shami K, Oeffinger KC, Erb NL, Willis A. American Cancer Society Colorectal Cancer Survivorship Care Guidelines. CA Cancer J Clin 2015; 6: 428-455.

2. Krishnan S, Lin EH, Gunn GB, Chandra A, Beddar AS. Conformal radiotherapy of the dominant liver metastasis: a viable strategy for treatment of unresectable chemotherapy refractory colorectal cancer liver metastases. Am J Clin Oncol 2006; 29: 562-567.

3. Ueno $H$, Hashiguchi $Y$, Shinto $E$, Mochizuki $H$, Hase $K$. Treatment strategy for early colorectal cancer. Nihon Rinsho 2011; 69 Suppl 3: 367-370.

4. Vigano L. Treatment strategy for colorectal cancer with resectable synchronous liver metastases: Is any evidence-based strategy possible? World J Hepatol 2012; 4: 237-241.

5. Tan $K Y$, Liu CB, Chen AH, Ding YJ, Jin HY, Seow-Choen $F$. The role of traditional Chinese medicine in colorectal cancer treatment. Tech Coloproctol 2008; 12: 1-6.

6. Yang YF, Ge JZ, Wu Y, Xu Y, Liang BY, Luo L. Cohort study on the effect of a combined treatment of traditional Chinese medicine and Western medicine on the relapse and metastasis of 222 patients with stage II and III colorectal cancer after radical operation. Chin J Integr Med 2008; 14: 251-256.

7. Ma HD, Deng YR, Tian Z, Lian ZX. Traditional Chinese medicine and immune regulation. Clin Rev Allergy Immunol 2013; 44: 229-241.

8. Lee YW, Chen TL, Shih YR, Tsai CL, Chang CC, Liang $\mathrm{HH}$. Adjunctive traditional Chinese medicine therapy improves survival in patients with advanced breast cancer: a population-based study. Cancer 2014; 120 : 1338-1344.

9. Dhariwal NS, Hugar SM, Harakuni S, Sogi S, Assudani $H G$, Mistry LN. A comparative evaluation of antibacterial effectiveness of sodium hypochlorite, Curcuma longa, and Camellia sinensis as irrigating solutions on isolated anaerobic bacteria from infected primary teeth. $J$ Indian Soc Pedod Prev Dent 2016; 34: 165-171.

10. Luo KW, Yue GG, Ko CH, Gao S, Lee JK, Li G, Fung KP. The combined use of Camellia sinensis and metronomic zoledronate in $4 T 1$ mouse carcinoma against tumor growth and metastasis. Oncol Rep 2015; 34: 477-487.

11. European Commission [homepage on the internet]. Directive 2010/63/EU on the protection of animals used for scientific purposes [cited 2013 Jan 16]. Available from:http://ec.europa.eu/environment/chemicals/lab_ani mals/legislation_en.htm.

12. Wu SY, Silverberg JI, Joks R, Durkin HG, Smith-Norowitz TA. Green tea (Camelia sinensis) mediated suppression of IgE production by peripheral blood mononuclear cells of allergic asthmatic humans. Scand J Immunol 2012; 76: 306-310.

13. Kim W, Jeong MH, Cho SH, Yun JH, Chae HJ, Ahn YK. Effect of green tea consumption on endothelial function and circulating endothelial progenitor cells in chronic smokers. Circ J 2006; 70: 1052-1057.

14. Kuriyama, S. Green tea consumption and prevention of coronary artery disease. Circ J 2010; 74: 248-249.

15. Wang QM, Gong QY, Yan JJ, Zhu J, Tang JJ, Wang MW. Association between green tea intake and coronary artery disease in a Chinese population. Circ J 2010; 74: 294-300.

16. Jin K, Gao W, Lu Y, Lan H, Teng L, Cao F. Mechanisms regulating colorectal cancer cell metastasis into liver (Review). Oncol Lett 2012; 3: 11-15.

17. Maruta M, Maeda K. Trends in the treatment for liver metastasis of colorectal cancer in Japan. Rozhl Chir 2011; 90: 669-673.

18. Chiang SP, Cabrera RM, Segall JE. Tumor Cell Intravasation. A Review in the Theme: Cell and Molecular Processes in Cancer Metastasis. Am J Physiol Cell Physiol 2016; 23: 224-226.

19. Dhillon AS, Hagan S, Rath O, Kolch W. MAP kinase signalling pathways in cancer. Oncogene 2007; 26: 3279-3290.

20. Collins QF, Liu HY, Pi J, Liu Z, Quon MJ, Cao W. Epigallocatechin-3-gallate (EGCG), a green tea polyphenol, suppresses hepatic gluconeogenesis through 5'-AMP-activated protein kinase. J Biol Chem 2007; 282: 30143-30149.

21. Babu PV, Liu D, Gilbert ER. Recent advances in understanding the anti-diabetic actions of dietary flavonoids. J Nutr Biochem 2013; 24: 1777-1789.

22. Hwang JT, Ha J, Park IJ, Lee SK, Baik HW, Kim YM, Park OJ. Apoptotic effect of EGCG in HT-29 colon cancer cells via AMPK signal pathway. Cancer Lett 2007; 247: 115-121.

23. Qi M, Elion EA. MAP kinase pathways. J Cell Sci 2005; 118: 3569-3572. 